\title{
Pemberdayaan Masjid sebagai Fungsi Sosial dan Ekonomi bagi Jamaah Pemegang Saham Unit Usaha Bersama
}

\author{
Ariana Suryorini \\ Universitas Islam Negeri Walisongo Semarang \\ Email: suryorini@walisongo.ac.id
}

\begin{abstract}
The function of the mosque is very universal, other than in the religious field, the mosque also has other functions which include religious/worship functions, educational functions, unifying functions of the people, social functions and economic functions. Islam places the mosque in a strategic position. Considering the strategic function of the mosque, it is necessary to provide good guidance, in terms of the physical building and the aspects of its prosperity. The mosque is expected to be a center of social and economic activity for its worshipers, not just a center for worship activities. Mosque empowerment is very important because it can provide a positive perspective related to the utilization of human resources through the empowerment of mosques for the welfare of Muslims. In the economic function of the empowerment of the Sirathal Mustaqim mosque through the activities of the Joint Business Unit (UB), whose ownership is pilgrims who have equity participation or capital ownership, which they refer to as shares of the business units they run, where profits are distributed to the owners or accompanying members of the capital in a meeting of capital owner members every year. The Joint Business Unit (UB) is named UB Rejeki Barokah, whose economic function activities are very diverse, both in the retail business of kiosks, services and goods credit business.
\end{abstract}

Abstrak: Fungsi masjid sangat universal, selain di bidang keagamaan, masjid juga mempunyai fungsi lain yang meliputi fungsi keagamaan/peribadatan, fungsi pendidikan, fungsi pemersatu umat, fungsi sosial dan fungsi ekonomi. Islam menempatkan masjid dalam posisi yang strategis. Mengingat fungsi masjid yang strategis maka perlu pembinaan secara baik, dari segi fisik bangunan maupun segi kegiatan pemakmurannnya. Masjid diharapkan bisa menjadi pusat aktivitas sosial dan ekonomi bagi para jamaahnya, tidak hanya menjadi pusat kegiatan ibadah saja. Pemberdayaan masjid menjadi hal yang sangat penting karena dapat memberikan perspektif positif terkait pemanfaatan sumber daya manusia melalui pemberdayaan masjid untuk kesejahteraan umat Islam. Dalam fungsi ekonomi pemberdayaan masjid Sirathal Mustaqim melalui aktivitas unit Usaha Bersama (UB), yang kepemilikannya adalah jamaah yang mempunyai penyertaan 
atau kepemilikan modal, yang mereka sebut seperti saham dari unit usaha yang mereka jalankan, dimana keuntungannya dibagikan kepada jamaah pemilik atau penyerta modal tersebut dalam rapat anggota Pemilik modal setiap tahunnya. Unit Usaha Bersama (UB) tersebut bernama UB Rejeki Barokah, yang aktivitas fungsi ekononominya sangat beragam, baik dalam usaha retail kios, jasa maupun usaha perkreditan barang.

Kata Kunci: Pemberdayaan, masjid, Fungsi Sosial Ekonomi.

\section{PENDAHULUAN}

Islam memiliki sistem ekonomi yang secara fundamental berbeda dari sistem-sistem yang tengah berjalan. Islam memiliki akar dalam syariat yang membentuk pandangan dunia sekaligus sasaran-sasaran dan strategi (maqashid asy-syaria'ah) yang berbeda dari sistem-sistem sekuler yang menguasai dunia saat ini. Sasaran-sasaran yang dikehendaki Islam secara mendasar bukan materiil. Konsep-konsep Islam tentang kebahagiaan manusia (falab) dan kehidupan yang baik (hayatan thayyibah) yang sangat menekankan aspek persaudaraan (ukhuwah), keadilan sosio-ekonomi, dan pemenuhan kebutuhan-kebutuhan spiritual umat manusia (Chapra, 2000). Fungsi masjid sangat universal, selain di bidang keagamaan, masjid juga mempunyai fungsi lain yang meliputi fungsi keagamaan/peribadatan, fungsi pendidikan, fungsi pemersatu umat, fungsi sosial dan fungsi ekonomi. Islam menempatkan masjid dalam posisi yang strategis.Mengingat fungsi masjid yang strategis maka perlu pembinaan secara baik, dari segi fisik bangunan maupun segi kegiatan pemakmurannnya (Rifa'I dan Fakhroroji, 2005).

Para pengelola unit Usaha Bersama (UB) di masjid Sirathal Mustaqim menjalankan aktivitasnya dalam pemberdayaan masjid tidak hanya sebagai tempat ibadah dan pendidikan saja, tetapi juga pemberdayaan masjid sebagai fungsi sosial dan ekonomi. Pemberdayaan masjid Sirathal Mustaqim dalam fungsi sosialnya melalui pengumpulan dan pembagian zakat kepada fakir miskin dan orang yang berhak menerima zakat. Selain itu juga berupaya menumbuhkan semangat produktivitas di kalangan umat muslim yang kurang mampu secara ekonomi, serta meminimalkan masalah kemiskinan. Fungsi sosial yang lainnya adalah aktivitas pembagian daging qurban tiap tahunnya.

Dalam fungsi ekonomi pemberdayaan masjid Sirathal Mustaqim melalui aktivitas unit Usaha Bersama (UB), yang kepemilikannya adalah jamaah yang mempunyai penyertaan atau kepemilikan modal, yang mereka sebut seperti saham dari unit usaha yang mereka jalankan, dimana keuntungannya dibagikan 
kepada jamaah pemilik atau penyertamodal tersebut dalam rapat anggota Pemilik modal setiap tahunnya. Unit Usaha Bersama (UB) tersebut bernama UB Rejeki Barokah, yang aktivitas fungsi ekononominya sangat bergam, baik dalam usaha retail kios, jasa maupun usaha perkreditan barang.

Berdasarkan pembahasan yang di paparkan dalam latar belakang penelitian di atas, maka peneliti merasa tertarik untuk melakukan penelitian dengan judul "Pemberdayaan Masjid Sebagai Fungsi Sosial Dan Ekonomi Bagi Jamaah Pemegang Saham Unit Usaha Bersama (UB) Di Masjid Sirathal Mustaqim Semarang". Namun yang dimaksud pemegang saham dalam penelitian ini adalah para pemilik atau penyerta modal kegiatan Usaha Bersama (UB).

\section{KAJIAN PEMBERDAYAAN MASJID SEBAGAI FUNGSI SOSIAL DAN EKONOMI}

Secara etimologi, pemberdayaan berasal dari kata dasar "daya" yang artinya kekuatan dan kemampuan. Dari makna tersebut, maka pemberdayaan dapat dimaknai sebagai suatu proses untuk memperoleh daya/ kekuatan/ kemampuan atau proses pemberian daya/ kekuatan/ kemampuan dari pihak yang memiliki daya kepada pihak yang kurang atau belum berdaya (Susanto, 2013). Pemberdayaan (empowerment) muncul sekitar tahun 1970-an dan terus berkembang di tahun 1990.Kemunculan konsep pemberdayaan ini hampir bersamaan dengan aliran-aliran eksistensialisme, fenomenologi dan personalisme.Dan berkembang pemikiran neo-marxisme, freudianisme, termasuk di dalamnya aliran-aliran strukuralisme dan sosiologi kritik sekolah Frankurt. Bermunculan juga konsep-konsep elit, kekuasaan, anti kemapanan, ideologi, pembebasan dan civil society (Ruslan, 2006).

Menurut aliran modern, pemberdayaan bertujuan untuk menemukan alternatif-alternatif baru dalam pembangunan masyarakat. Pada hakikatnya, proses pemberdayaan dapat dipandang sebagai depowerment dari sistem kekuasaan yang mutlak absolut (intelektual, religius, politik, ekonomi dan militer). Konsep ini berlandaskan pada kemanusiaan (bumanisme) (Ruslan, 2006). Istilah pemberdayaan masyarakat mengacu pada kata empowerment yang berarti penguatan.Yaitu sebagai upaya mengaktualisasikan potensi yang sudah dimiliki sendiri oleh masyarakat.Jadi pendekatan pemberdayaan masyarakat titik beratnya adalah penekanan pada pentingnya masyarakat lokal yang mandiri sebagai suatu sistem yang mengorganisir diri mereka.Maka pendekatan pemberdayaan 
masyarakat yang diharapkan adalah yang dapat memposisikan individu sebagai subjek bukan sebagai obyek (Setiana, 2007).

Adapun pengertian masjid, secara istilah adalah tempat sujud, yaitu tempat umat islam mengerjakan sholat, zakat dan untuk hal-hal yang berhubungan dengan dakwah islamiyah (Mujid, 1994). Secara bahasa, kata masjid merupakan ungkapan yang berasal dari bahasa Arab yaitu sajada, yasjudu, sujudan, masjadun, wa misjadun yang berarti sujud atau menundukan kepala hingga dahi menyentuh tanah. Kalian ilmu sharaf menyebutnya dengan isim makan, bermakna kata benda, mengindikasikan tempat. Kata masjid termasuk kategori kalimat sima'i yaitu sebuah istilah untuk kata yang harkatnya menyalahi kaidah gramatika bahasa Arab karena masjid seharusnya masjad dengan wazan maf'al.

Dengan memahami definisi di atas, bisa dipahami bahwa untuk mengupayakan pemakmuran masjid secara baiktentu memerlukan dana yang besar. Karena memang pendanaan masjid melalui kotak amal tidak terlalu banyak sementara kebutuhan untuk pemakmuran masjid membutuhkan dana yang banayak. Oleh karaena itu pengurus masjid perlu mengupayakan usaha dana guna menopang seluruh kegiatan masjid. Diantara usaha dana yang bisa dilakukan oleh pengurus masjid antara lain (Affandi, 2013); a) Mengupayakan adanya donatur tetap dari jamaah setempat atau dermawan lain yang diambil infaqnya setiap bulan. b) Program donatur tetap ini tidak hanya di peruntukkan bagi jamaah yang kaya, tetapi juga untuk mereka yang hidupnya pas-pasan, namun ada semangat untuk berinfaq dengan cara untuk menyisihkan uang. c) Menghimpun dan mengelola zakat fitrah, infaq, sedekah, dan wakaf. d) Baitul maaal wat tanwil yang menggunakan system syariah islam guna menghimpun dana umat dan mengembangkannya untuk kepentingan umat. e) Penyewaan ruang aula serba guna yang dimiliki masjid serta fasilitasnya untuk berbagai macam aktifitas yang baik serta walimah,,seminar dan sebagainya dengan ketentuan yang sesuai dengan ajaran Islam. f) Penyewaan inventaris masjid seperti sound system, kursi dan sejenisnya serta memiliki barang-barang seperti mobil, motor dan sebagainya. Dan g) usaha-usaha lain yang halal dan tidak mengikat (Dahlan, 2001).

Fungsi utama masjid adalah tempat sujud kepada Allah SWT, tempat shalat, dan tempat beribadah kepada Nya. Lima kali sehari semalam umat Islam dianjurkan mengunjungi masjid guna melaksana kan shalat berjamaah. Masjid juga mempakan tempat yang paling banyak dikumandangkan nama Allah melalui azan, qamat, tasbih, tahmid, tahlil, istigfar, dan ucapan lain yang dianjurkan dibaca di masjid sebagai bagian dan lafaz yang berkaitan dengan pengagungan asma Allah. Selain itu fungsi masjid meliputi; a) Masjid merupakan tempat kaum 
muslimin beribadah dan mendekatkan diri kepada Allah SWT. b) Masjid adalah tempat kaum muslimin beri'tikaf, membersihkan diri, menggembleng batin untuk membina kasadaran dan mandapatkan pengalaman batin/keagamaan sehingga selalu terpelihara keseimbangan jiwa dan raga serta keutuhan kepribadian. c) Masjid adalah tempat bermusyawarah kaum muslimin guna memecahkan persoalan-persoalan yang timbul dalam masyarakat. d) Masjid adalah tempat kaum muslimin berkonsultasi, mengajukan kesulitan-kesulitan, memima bantuan dan pertolongan. e) Masjid adalah tempat membina keutuhan ikatan jamaah dan kegotong-royongan di dalam mewujudkan kesejahteraan bersama. f) Masjid dengan majelis taklimnya mempakan wahana untuk meningkatkan kecerdasan dan ilmu pengetahuan muslimin. g) Masjid adalah tempat pembinaan dan pengembangan leader kader pimpinan umat. h) Masjid tempat mengumpulkan dan menyimpan, dan membagikannya. Dan i) Masjid tempat melaksanakan pengaturan dan supervisi sosial.

Bagaimana dengan manajemen? Jika dalam perpektif sosiologi, masyarakat disebut sebagai mahluk sosial (animal society dan dalam perpektif politik manusia disebut sebagai mahluk politik (zoon politicon), maka dalam perpektif manajeman, masyarakat disebut dengan istilah seperti masyarakat manajerial (managerial society), manusia organisasional (organizational man), masyarakat organisasional (organizational society), manusia administrative (administrative man) (Choliq, 2011).

Sumber daya manajemen bisa dipilah menjadi dua. Pertama, Sumber Daya Manusia. Sumber daya manusia (buman resources) juga dinamakan personalia (personel) adalah orang yang bekerja dalam organisasi atau orang yang melakukan berbagai aktivitas untuk mencapai tujuan organisasi (Silalahi, 2002: 7). Sumber daya manusia dibedakan menjadi manajer dan karyawan .Manajer adalah orang yang memiliki tugas, kewajiban, dan tanggung jawab mengelola sumber-sumber dan tugas-tugas untuk mencapai tujuan organisasi. Karyawan adalah orang yang melaksanakan kegiatan-kegiatan yang secara langsung untuk mencapai tujuan organisasi tersebut.

Kedua, Sumber Daya Material. Sumber daya materials (material resources) adalah berbagai fasilitas atau sarana dan prasarana yang dibutuhkan untuk mendukung pencapaian tujuan organisasi (Silalahi, 2001). Meskipun manusia menjadi elemen penting namun bila tidak disertai sumber daya material ini makatujuan organisasi tidak akan tercapai.

Terdapat empat unsur penting dalam manajemen. Pertama, Perencanaan Dalam Manajemen. Perencanaan merupakan dasar yang digunakan untuk memilih tujuan dan menentukan langkah-langkah serta cakupan pencapaiannya. 
Merencanakan bermakna memberdayakan seluruh komponen organisasi seperti sumber daya manusia (buman resources), sumber daya alam (natural resources) dan sumber daya yang lain (other resources), Stoner menyebutkan, bahwa perencanaan sebagai suatu proses penentuan tujuan dan tindakan yang sesuai guna mencapai tujuan tersebut (Stoner, 1995). Terry menyebutkan, perencanaan adalah menyeleksi dan menghubungkan fakta-fakta, membuat dan menggunakan asumsi-asumsi yang berkaitan dengan penggambaran dan penyusunan kegiatan yang akan dilakukan untuk mencapai hasil yang diinginkan (Terry, 2003). Roger A. Kauffman dalam Fattah berpendapat bahwa yang dimaksud perencanaan adalah proses penentuan tujuan atau sasaran yang hendak dicapai dan menetapkan jalan dan sumber yang diperlukan untuk mencapai tujuan seefisien dan seefektif mungkin (Fattah, 2004).

Dari pendapat-pendapat di atas dapat disimpulkan bahwa perencanaan dalam fungsi manajemen ini adalah suatu proses untuk menentukan tujuan atau sasaran yang hendak dicapai dan menetapkan jalan dan sumber yang diperlukan untuk mencapai tujuan seefisien dan seefektif mungkin. Berdasarkan pengertian tersebut, maka perencanaan mempunyai karakteristik, yang disebutkan oleh Siswanto sebagai berikut (Siswanto, 2005); Perencanaan harus menyangkut masa yang akan datang; Terdapat suatu elemen indikasi pribadi atau organisasi, yaitu rangkaian tindakandi masa yang akan datang dan akan diambil oleh perencana; dan Masa yang akan datang, tindakan dan identifikasi pribadi, serta organisasi merupakan unsur yang penting dalam setiap perencanaan. Suatu perencanaan belum jelas dapat tercapai sesuai dengan harapan atau tidak, karena itu penilaian terhadap kemungkinan tercapainya sasaran merupakan langkah penting dalam proses perencanaan.

Perencanaan bertujuan untuk memberi pegangan bagi manajer agar mengetahui arah yang hendak dituju, mengurangi dampak perubahan, mengurangi pemborosan dan kesia-siaan, serta menetapkan acuan untuk memudahkan dalam melakukan pengawasan (Choliq, 2011). Kalau semua pihak telah menyadari benar ke mana organisasi hendak menuju, maka apa yang harus diperbuat oleh masing-masing orang dalam organisasi sesuai dengan jabatan dan tugas masing-masing untuk mencapai tujuan, maka mulailah mereka mengkoordinasikan.

Kedua, Pengorganisasian dalam Manajemen. Pengorganisasian adalah langkah yang ditempuh setelah tujuan dan rencana-rencana organisasi ditetapkan, yaitu dengan merencanakan dan mengembangkan organisasi agar dapat melaksanakan berbagai program yang telah direncanakan secara sukses.Terry, menyebutkan bahwa "pengorganisasian adalah pembentukan 
hubungan perilaku efektif antar orang sehingga mereka dapat bekerja bersamasama secara efisien dan mencapai kepuasan pribadi dalam mengadakan tugastugas di bawah kondisi lingkungan yang diberikan guna mencapai tujuan" (Terry, 2003). Stoner, berpendapat bahwa "pengorganisasian merupakan proses mengajak atau mengikutsertakan dua orang atau lebih dalam bekerja bersamasama dalam suatu cara yang terstruktur guna mencapai suatu tujuan yang spesifik atau menyusun tujuan-tujuan" (Stoner, 1995).

Ketiga, Penggerakan dalam Manajeman. Secara umum actuating diartikan sebagai menggerakan orang lain. Penggerakan hakekatnya merupakan suatu usaha dan dapat bekerja untuk mencapai tujuan yang telah ditetapkan secara efektif dan efisien. Actuating atau disebut juga "gerakan aksi" mencakup kegiatan yang dilakukan seorang manager untuk mengawali dan melanjutkan kegiatan yang ditetapkan oleh unsur perencanaan dan pengorganisasian agar tujuantujuan dapat tercapai. Actuating mencakup penetapan dan pemuasan kebutuhan manusiawi dari pegawai-pegawainya, memberi penghargaan, memimpin, mengembangkan dan memberi komponsasi kepada mereka. Pada dasarnya penggerakan sangat erat kaitannya dengan unsur manusia yang ada dalam organisasi. Kegiatan organisasi akan sangat ditentukan oleh sejauh mana unsur manusia dapat menggunakan seluruh unsur-unsur lainnya serta mampu melaksanakan tugas-tugas yang telah ditetapkan (Terry, 2013).

Tujuan penggerakan dalam organisasi adalah usaha atau tindakan dari pemimpin dalam rangka menimbulkan kemauan dan membuat bawahan tahu pekerjaannya sehingga secara sadar menjalankan tugasnya sesuai dengan yang telah ditetapkan sebelumnya. Selain itu tujuan penggerakan dirincikan sebagai berikut: Mengembangkan rasa tanggung jawab, Pemberian komando, Mengembangkan rasa tanggung jawab, Pemeliharaan modal, Komunikasi, dan pengembangan eksekutif.

Keempat, Pengawasan/Kontrol Dalam Manajeman. Kontrol atau pengawasan, juga disebut pengendalian merupakan fungsi manajemen yang mengukur tingkat efektifitas kerja personal dan tingkat efisiensi penggunaan metode serta alat-alat tertentu dalam usaha mencapai tujuan.Tolok ukur pengawasan biasanya adalah program kerja ataupun norma-norma yang ditetapkan bersama. Kontrol meliputi pemeriksaan apakah segala sesuatunya telah berjalan sesuai dengan rencana, instruksi-instruksi, dan prinsip-prinsip yang telah ditetapkan. Hal ini dimaksudkan agar dapat ditemukan kelemahankelemahan dan kesalahan-kesalahan, kemudian dibetulkan dan dicegah agar tidak terulang. 
Manajer dalam berbagai organisasi menghadapi isu penting berhubungan dengan fungsi pengontrolan.Sebab kegiatan pengontrolan dilakukan untuk mengusahakan agar pelaksanaan kegiatan dan tujuan tercapai sesuai dengan rencana yang telah ditentukan. Maksud pengontrolan adalah mewaspadai manajer untuk satu masalah sebelum hal itu menjadi semakin parah, membahayakan atau krisis secara potensial. Pada tingkat manajemen puncak, masalah terjadi bila tujuan organisasi tidak tercapai, sedangkan pada tingkat menengah atau bawah suatu masalah terjadi jika sasaran-sasaran departemental untuk mana manajer bertanggung jawab tidak tercapai.

Dalam sebuah usaha ekonomi berupa Kegiatan Unit Usaha Bersama oleh takmir masjid, memerlukan dana yang tidak sedikit jumlahnya. Kurang baiknya pendanaan dapat menyebabkan terhambatnya kegiatan kegiatan yang telah diprogramkan. Oleh karena itu, masalah Penggalian dana perlu mendapat perhatian yang serius dan penanganan yang sungguh-sungguh melalui elemen manejemen yang ada. Perlu diperhatikan beberapa sumber pendanaan yang mungkin diakses oleh takmir masjid. Pertama, Sumber dana tetap. Sumber dana tetap merupakan sumber utama bagi keuangan masjid. Sumber dana ini berupa pemasukan yang secara rutin dan Periodik mengisi kas masjid. Sifat Periodik bisa berarti harian, mingguan atau bulanan, tergantung kebijakan masing masing takmir. Sumber dana tetap meliputi sumbangan dari pengurus takmir, jamaah masjid dan pihak lain yang secara teratur dan berkala memberikan sumbangan bagi kas masjid. Sumber dana tetap bersifat teratur, artinya setiap periodik ada pemasukan meskipun jumlahnya tidak selalu sama, sumber dana tetap yang berasal dari pihak lain di luar pengurus dan jamaah, dapat berasal dari donatur yang secara rutin memberikan sumbangan bagi kas masjid. Letak perseorangan yang diberikan sebulan sekali misalnya,Dengan jumlah yang tetap dan diberikan secara teratur, merupakan contoh dari sumber dana ini.

Kedua, Sumber dana tidak tetap. Sumber dana tidak tetap memiliki karakteristik kebalikan dari sumber dana tetap. Sumber dana tidak tetap adalah sumbangan dana dari pengurus, jamaah atau pihak lain yang sifatnya suka rela dan tidak rutin. Sumber dana ini tidak dapat diprediksi, baik jumlah maupun waktunya I. Seseorang sewaktu waktu dapat menyumbangkan sejumlah uang kepada tak mir masjid, maka sumbangan orang tersebut merupakan contoh dari sumber dana ini. Keberlangsungan sumber dana ini memang tidak dapat dipastikan mengingat Inisiatif ada pada pihak pemberi sumbangan. Bisa jadi di satu waktu banyak pihak yang memberikan sumbangan tanpa diminta, namun di waktu yang lain sama sekali tidak ada sumbangan dari seorang pun. 
Takmir masjid yang baik dan amanah, serta memiliki kegiatan yang rutin, produktif dan berkualitas dapat merangsang pihak lain untuk memberikan bantuan bagi keuangan masjid. Sebaliknya, bila tak mir tidak dapat menghadirkan simpati kepada pihak lain, sementara kegiatan yang ada juga terkesan monoton, maka dapat menjadikan pihak lain enggan memberikan sumbangan kepada takmir masjid yang dinilainya kurang amanah dan kurang profesional. Mereka akan mencari masjid lain yang memiliki takmir masjid profesional dan kegiatannya pun berkualitas. Dengan kata lain, penilaian masyarakat kepada takmir masjid sedikit banyak Akan memberikan pengaruh yang berarti bagi para pihak yang hendak menginfaqkan sebagian rezeki yang diperolehnya. Takmir masjid yang dinilai amanah akan lebih diprioritaskan oleh masyarakat bila hendak menginfaqkan sebagian hartanya.

Ketiga, Sumber Dana Insidental. Sumber dana insidental merupakan sumbangan dari berbagai pihak yang timbul karena adanya inisiatif takmir mengaukan permohonan dana, Contoh sumber dana ini adalah: pengajuan proposal untk rehabilitasi bangunan masjid, atau pengajuan proposa untuk pengajuan kegiatan masjid. Pihak lain yang dimaksud adalah pemerintah, instansi swasta, lembaga donor, yayasan, atau organisasi dan sebagainya.

Keempat, Sumber Dana Usaha Masjid. Sumber dana usaha masjid merupakan panggilan dana dengan cara melakukan aktivitas ekonomi yang dapat menghasilkan uang untuk menunjang kas masjid, aktivitas ekonomi yang dipilih biasanya di bidang jasa dan perdagangan, meskipun tidak menuntut kemungkinan usaha ekonomi masjid di bidang produksi.

Aktivitas ekonomi dibidang jasa diantaranya berupa membentuk even organizer (EO) islami, di mana EO ini memfasilitasi berbagai macam kegiatan, seperti pelatihan walimatul urs, bisa pula dalam bentuk penyewaan jasa gedung untuk berbagai kegiatan, perpustakaan, fotocopy, klinik, radio islami, dan lainlain. Aktivitas ekonomi di bidang perdagangan yang bisa dikembangkan oleh takmir masjid dapat berupa mendirikan dan mengelola minimarket atau toko, yang menjual berbagia macam kebutuhan sehari-hari dan produk-produk islami, seperti kalender hijriah, kaset muratal, al-qur'an, alat perlengkapan shalat dan lain sebaginya. Ekonomi Masjid dikelola oleh bidang usaha dana dengan kewenangan kebijakan teknis usaha, adapun laba yang diperoleh dari ekonomi masjid, sebagian dimasukn ke kas masjid melalui bendahara. Sebagian lagi disisakan sebagai tambahan modal (Al-Faruq, 2010). 


\section{PENGUATAN UNIT USAHA BERSAMA MASJID SIRATHAL MUSTAQIM}

Masjid Sirathal Mustaqim sebagai properti publik membutuhkan pengelolaan (manajeman) dalam rangka pemeliharaan dan pelaksanaan fungsinya bagi masyarakat. Semakin luas fungsi masjid bagi masyarakat, maka semakin dibutuhkan sumber daya manajerial yang tinggi. Pengelola/pengurus, Takmir masjid dan jamaah masjid merupakan kekuatan utama dalam menjalankan kegiatan/aktivitas, fungsi masjid tersebut secara efektif dan efisien. Sumber daya yang dimilki Unit Usaha Bersama (UB) Rejeki Barokah adalah tenaga yang memilki pengetahuan dan keahlian atau skill dibidang kewirausahaan. Ada yang memiliki pendidikan formal S1, ada juga yang PNS dan pensiunan PNS, serta beberapa diantaranya ada yang seorang wirausahawan. Hal tersebut sangat berpengaruh penting dalam pengelolaan dan pengembangan serta kebijakan yang diterapkan demi kemajuan Unit Usaha Bersama (UB) Rejeki Barokah. Dengan adanya sumber daya manusia yang kompeten khususnya pengelolanya, maka dapat melahirkan strategi dan program-program yang baik dalam menjalankan usaha tersebut, sehingga dapat mensejahterakan anggotanya. Dalam menjalankan proses kegiatannya tersebut proses perencanaan, pengorganisasian, penggerakan dan pengawasan yang sistematis serta maksimal akan mengembangkan potensi yang ada.

Sumber daya materials (material resources) adalah berbagai fasilitas atau sarana dan prasarana yang dibutuhkan untuk mendukung pencapaian tujuan organisasi.Sumber daya material terdiri atas: sumber finansial (fiancial resources), sumber fisik (physical resources), sumber informasi (information resources, dan ide-ide (ideas). Financial adalah modal yang diperlukan untuk membiayai aktivitas. Sumber finansial berasal dari infaq dan shodaqoh serta donatur jamaah masjid tersebut. Fisik adalah segala fasilitas yang dibutuhkan untuk mendukung efisiensi dan efektivitas kerja, seperti: gedung, perlengkapan kantor, lokasi, mesin-mesin, dan bahan mentah (raw materials), dan lain-lain. Di lihat berdasarkan infrastruktur masjid Sirathal Mustaqim ini, desain bagunannya sudah rapi dan profesional, hal ini bisa dilihat dari bangunan atau kondisi fisik masjid yang masih bagus, serta sudah berdirinya fasilitas-fasilitas yang diperuntukkan untuk jamaah masjid. Ketersediaan ruang kantor masjid, ruang untuk rapat pengurus, kamar tidur tamu, serta mobil ambulans, tempat parkir yang luas, toko retail, menjadikan masjid ini semakin lengkap fasilitasnya dalam pemenuhan sarana prasarana yang dibutuhkan oleh jamaahnya, sekaligus menunjang kegiatan operasional manajerial masjid. 
Informasi adalah gambaran tentang hasil aktivitas baik lisan maupun tulisan yang dibutuhkan pada saat tertentu, termasuk peraturan-peraturan, pedoman kerja, dan lain-lain. Ide-ide adalah pemikiran konseptual atau segala upaya termasuk teknologi yang diciptakan dan digunakanuntuk mengefektifkan dan mengefisienkan pencapaian tujuan, seperti: metode, prosedur, teknik dan strategi yang digunakan. Pengelola/pengurus masjid Sirathal Mustaqim dalam menjalankan aktivitas dan pemberdayaan masjid sebagai fungsi sosial dan ekonomi meliputi dua bidang; Idarah Bina'il ma'diy (Physical Management) yaitu manajeman secara fisik yang meliputi kepengurusan masjid, pengaturan pembangunan fisik masjid, pemeliharaan, kebersihan, ketertiban dan keindahan masjid (termasuk taman dan lingkungan masjid), pemeliharaan tata tertib dan keamanan masjid, pengaturan keuangan serta administrasi masjid. Dan Idarah Bina'il Ru'biy (Functional management) yaitu pengaturan tentang pelaksanaan masjid sebagai ruang pembinaan spiritual, pendidikan dan kemasyarakatan.

Pengelolaan unit Usaha Bersama (UB) yang dilakukan oleh pengurus bisa memberikan keuntungan secara ekonomi bagi jamaah pemilik modal dalam pemberdayaan masjid Sirathal Mustaqim sebagai fungsi ekonomi. Kegiatan ekonomi masjid memiliki potensi yang tinggi dengan adanya pasar yang tetap (captive market), yaitu masyarakat yang menjadi jamaah masjid dan masyarakat yang lain yang memanfaatkan usaha dari kegiatan masjid tersebut. Loyalitas pasar usaha masjid didorong oleh manfaat dari keuntungan yang dipergunakan bagi kepentingan masjid itu sendiri.

Bentuk dari kegiatan ekonomi di Masjid sirathal Mustaqim adalah unit Usaha Bersama (UB) Rejeki Barokah, modal usahanya berasal dari para jamaah masjid tersebut, yang dikelola oleh pengurus UB, yang hasil keuntungannya dibagi pada pemilik modal berdasarkan jumlah modal yang di setor. Kegiatan usahanya meliputi; a) Bidang usaha Retail meliputi penjualan dengan membuka toko di area lingkungan masjid dan investasi. Dengan adanya usaha retail ini, maka keuntungan dari penjualan barang-barang ditoko hasilnya bisa dibagikan pada para anggota pemilik atau penyerta modal usaha di UB Rejeki Barokah secara syariah, dengan akad Mudharabah, yakni suatu akad kerjasama usaha antara pemilik dana dan pengelola dana untuk melakukan kegiatan usaha, laba dibagi atas dasar nisbah bagi hasilmenurut kesepakatan kedua belah pihak (Salman, 2012). b) Jasa pembelian beras zakat, sapi qurban dan bingkisan lebaraan.

UB Rejeki Barokah memberikan layanan pembelian beras zakat dan pengadaan bingkisan lebaran menjelang hari raya Idul Fitri dan pengadaan sapi qurban menjelang hari raya Idul Adha. Jasa ini sangat membantu dan 
mempermudah anggotanya serta jamaah masjid Sirathal Mustaqim dalam menjalanakan ibadah keagamaan. C) Usaha Penyediaan modal untuk usaha instan. Jasa penanyediaan modal ini sifatnya masih terbatas dalam jumlah nominal yang kecil dan untuk jenis usaha kecil atau usaha mikro. Hal ini dikarenakan jumlah modal yang masih relatif kecil. D) Penyedian modal usaha basket marketing produk sembako. Jasa usaha basket marketing ini berisi barang-barang kebutuhan pokok atau sembako, dengan harga minimal Rp 50.000 (lima puluh ribu rupiah). E) Unit usaha perkreditan barang dengan sistem bagi hasil. Pelayanan jasa ini berdasarkan akad atau perjanjian bersama yang sudah disepakati. F) Jasa penyelenggara arisan sirkah kendaraan. Arisan sirkah kendaraan ini akad perjanjiannya sesuai kesepakatan antar UB Rejeki Barokah dengan anggota peserta arisan sepeda motor. Undian penerima sepeda motor dengan cara diundi, yang namanya keluar maka mereka yang mendapatkan sepeda motor tersebut, dan BPKB ditahan oleh pengurus, akan diberikan sesuai nama pemilknya jika arisan sirkah sepeda motor tersebut selesai.

Dengan adanya kegiatan usaha bersama (UB) yang beragam, maka diharapkan akan memberikan keuntungan secara ekonomi bagi para jamaah pemilik modal UB Rejeki Barokah. Pembagian hasil usaha diberikan dalam rapat anggota jamaah masjid yang memiliki atau menanamkan modalnya di UB Rejeki Barokah. Kegiatan Usaha produktif ini menciptkan nilai tambah dan membantu mendorong pertumbuhan finasial atau ekonomi bagi jamaah masjid tersebut, dan bagi unit usaha bersama masjid Sirathal Mustaqim yang berlandaskan sistem syariah. Dalam Pengelolaannya sudah sesuai dengan fungsifungsi manajeman yang meliputi Perencanaan (planning) adalah fungsi dasar (fundamental) manajemen, organizing, actuating, dan controlling.

Perencanaan ini adalah dinamis. Perencanaan ini ditunjukan pada masa depan yang penuh dengan ketidakpastian, karena adanya perubahan kondisi dan situasi.Hasil perencanaan baru akan diketahui pada masa depan, Agar resiko yang ditangung itu relatif kecil, hendaknya semua kegiatan, tindakan,dan kebijakan direncanakan terlebih dahulu.Perencanaan ini adalah masalah" memilih", artinya memilih tujuan, dan cara terbaik untuk mencapai tujuan tersebut dari beberapa alternatif yang ada. Tanpa alternatif, perencanaan pun tidak ada. Perencanaan merupakan kumpulan dari beberapa keputusan (Salman, 2012). Perencanaan membantu peningkatan daya gun dan hasil guna organisasi (Hasibuan, 2001).

Pengorganisasian merupakan suatu proses untuk merancang struktur formal, mengelompokkan, dan mengatur serta membagi tugas-tugas atau pekerjaan diantara para anggota organisasi, agar tujuan organisasi dapat dicapai 
dengan efisien. Proses pengorganisasian dapat ditunjukan dengan tiga langkah berikut: Perincian seluruh pekerjaan yang harus dilaksanakan untuk mencapai tujuan organisasi. Pembagian beban pekerjaan total menjadi kegiatan-kegiatan yang secara rasional dapat dilakukan oleh satu orang. Dan Pengadaan dan pengembangan suatu mekanisme untuk mengkoordinasikan pekerjaan para anggota organisasi menjadi kesatuan yang terpadu dan humanis (Handoko, 2008).

Fungsi actuating=directing=leading adalah fungsi manajemen yang terpenting dan paling dominan dalam proses manajemen. Fungsi ini baru dapat diterapkan setelah rencana, organisasi, dan anggota ada. Jika fungsi ini diterapkan, maka proses menajemen dalam merealisasi tujuan dimulai. Penerapan fungsi ini sangat sulit, rumit, dan kompleks, karena karyawan tidak dapat dikuasai sepenuhnya.Hal ini disebabkan anggota adalah makhluk hidup yang mempunyai perasaan, pikiran, harga diri, cita-cita dan lain-lain (Handoko, 2008). Pengarahan ini dapat dilakukan dengan cara persuasif atau bujukan dan instruksi, tergantung cara mana yang efektif. Pengarahan disebut efektif jika dipersiapkan dan dikerjakan dengan baik serta benar oleh anggota yang ditugasi.Untuk melaksanakan secara efektif kegiatan tersebut, maka manajer mengambil tindakan-tindakan yang mana tindakan-tindakan tersebut meliputi, perintah, intruksi, komunikasi, nasehat, dan lain-lain (Pangliyakim. 1984).

Pengendalian atau controlling adalah suatu usaha sistematik untuk menetapkan standar kinerja dengan sasaran perencanaan, mendesain sistem umpan balik informasi, membandingkan kinerja aktual dengan standar yang telah ditetapkan untuk menjamin bahwa semua sumber daya perusahaan yang sedang digunakan secara lebih efisien dan efektif guna mencapai sasaran perusahaan.Tujuan pengendalian menurut GR.Terry: ada 3 yaitu: Supaya proses pelaksanaan dilakukan dengan ketentuan-ketentuan dari rencana. Melakukan tindakan perbaikan (Corective), jika terdapat penyimpangan-penyimpangan (Deviasi). Supaya tujuan yang dihasilkan sesuai dengan rencananya.

Pengendalian bukan hanya untuk mencari kesalahan-kesalahan, tetapi berusaha untuk menghindari terjadinya kesalahan-kesalahan serta memperbaikinya jika terdapat kesalahan. Jadi pengendalian dilakukan sebelum proses, saat proses, dan setelah proses, yakni hingga hasil akhir telah diketahui. Dengan pengendalian diharapkan juga agar pemanfaatan semua unsure manajemen efektif dan efisien (Terry dan Rue, 2000). 


\section{KESIMPULAN}

Dari hasil temuan dalam penelitian ini terlihat bahwa : Potensi sumber daya yang dimiliki masjid Sirathal Mustaqim dalam pemberdayaan masjid sebagai fungsi sosial yaitu masjid sebagai ruang pembinaan spiritual, pendidikan dan kemasyarakatan. Sedangkan Fungsi ekonomi masjid meliputi, pertama sumberdaya manusia yang dimiliki masjid, pengurusnya adalah tenaga yang mempunyai keahlian dan ketrampilan dibidang kewirausahaan. Kedua, memiliki infrastruktur atau sarana prasarana yang memadai baik dari bangunan fisik masjid yang bagus, maupun kelengkapan pendukung lainnya yang menunjang kegiatan operasional manajerial masjid, seperti adanya kantor, ruang rapat, kamar tamu, adanya mobil ambulans, toko retail kebutuhan hidup/sembako, tempat parkir yang luas. Pengelolaan unit usaha bersama atau UB Rejeki Barokah yang dilakukan pengurus bisa memberikan keuntungan secara ekonomi bagi jamaah pemilik modal dalam pemberdayaan masjid Sirathal Mustaqim. Hal ini terwujud Dengan adanya kegiatan usaha bersama (UB) yang beragam, maka diharapkan akan memberikan keuntungan secara ekonomi bagi para jamaah pemilik modal UB Rejeki Barokah. Pembagian hasil usaha diberikan dalam rapat anggota jamaah masjid yang memiliki atau menanamkan modalnya di UB Rejeki Barokah.Kegiatan Usaha produktif ini menciptkan nilai tambah dan membantu mendorong pertumbuhan finasial atau ekonomi bagi jamaah masjid tersebut, dan bagi unit usaha bersama masjid Sirathal Mustaqim yang berlandaskan sistem syariah. Pengelolaannya menggunakan fungsi-fungsi manajeman yang meliputi planing, organizing, actuating dan controlling.

\section{DAFTAR PUSTAKA}

Abdul Choliq, 2011. Pengantar Manajeman. Semarang: rafi Sarana Perkasa (RPS)

Azwar, Saifuddin, 2007. Metode Penelitian, Yogyakarta: Pustaka Pelajar

Daft, Richard L. 2002. Manajemen (Judul asli: Management, alih bahasa Emil Salim, Tinjung Desy Nursanti, Maryanni Hermanto), Ed. 5. Jakarta: Erlangga 
Danandjaja, Andreas A. 1991. "Motivasi: Teori dan Praktek dalam Hubungannya dengan Kepemimpinan". Bank dan Manajemen, No. 8, Januari/Februari: 61-63.

Effendy, Onong Uchjana. 2004. Dinamika Komunikasi. Bandung: Remaja Rosdakarya.

Fattah, Nanang. 2004. Landasan Manajemen Pendidikan. Bandung: Remaja Rosda Karya.

George R.Terry dan Leslie W. Rue. 2000. Dasar-dasar manajemen, Jakarta: PT Bumi Aksara.

Griffin, Ricky W. 2002. Manajemen (Judul asli: Management, alih bahasa Gina Gania), Jilid 1, Ed. 7. Jakarta: Erlangga.

Handoko, T.Hani. 2001. Manajemen. Edisi kedua. Yogyakarta: BPFE.

Hasibuan, H. Malayu. 2004. Manajemen: Dasar, Pengertian, dan Masalah. Ed. Revisi. Jakarta: Bumi Aksara.

Hijjaturosy. 2007. “Kepemimpinan yang Efektif'. Kepemimpinan: Pengembangan Organisasi, Team Building, dan Perilaku Inovatif. M. Mas'ud Said. Malang: UIN Malang.

Irwan, 2004. Metodologi Penelitian

John M.Echols dan Hasan Shadily, 2005. Kamus Inggris-Indonesia, Jakarta : Gramedia

Kautsar Riza Salman, 2012. Akuntansi Perbankan Syariah, Padang: Akademia Permata

Narbuko cholid, dan Achmadi, Abu, 2005. Metodologi Penelitian, Jakarta: Bumi Aksara

Nawaw, H. 2004. Manajemen Sumber Daya Manusia untuk Bisnis Kompetitif. Yogyakarta: UGM Press. 
Nawawi Hadari, 2005, Manajemen Strategik Organisasi Non Profit Bidang Pemerintahan, Yogyakarta:Gajah Mada University Press

Pidarta, Made. 2004. Manajemen Pendidikan Indonesia. Jakarta: Rineka Cipta.

Rangkuti, Freddy. 2006. Analisis SWOT Teknik Membedah Kasus Bisnis: Reorientasi Konsep Perencanaan Strategis Menghadapi Abad 21. Jakarta: Gramedia Pustaka Utama.

Siagian, Sondang P. 2000. Manajemen Abad 21.Jakarta: Bumi Aksara.

Silalahi, Ulber. 2002. Pemahaman Praktis Asas-asas Manajemen. Bandung: Mandar Maju.

Siswanto, H.B. 2005. Pengantar Manajemen. Jakarta: Bumi Aksara.

Sugiyono, 2007.Metode Penelitian Pendidikan Pendekatan Kuantitatif, Kualitatif dan R\&D, Bandung: Alfabeta

Stoner, James AF. 1995. Manajemen. Jakarta: Erlangga.

Terry, Geogge, 2013, Prinsip-prinsip Manajemen, Jakarta:PT Bumi Aksara

Terry, George R. 2003. Prinsip-prinsip Manajemen (Judul asli: Guide to Management). Penerjemah J. Smith D.F.M. Jakarta: Bumi Aksara.

Terry, George R. 2003. Prinsip-prinsip Manajemen.Jakarta: Bumi Aksara.

Wahjosumidjo. 1987. Kepemimpinan dan Motivasi. Jakarta: Ghalia Indonesia.

Winardi, J. 2004. Motivasi: Pemotivasian dalam Manajemen. Jakarta: Raja Grafindo Persada. 